RECLAIMING AMERICA 



\title{
RECLAIMING AMERICA
}

\author{
Nike, Clean Air, \\ and the \\ New National Activism
}

RANDY SHAW

UNIVERSITY OF CALIFORNIA PRESS

Berkeley Los Angeles London 
University of California Press

Berkeley and Los Angeles, California

University of California Press, Ltd.

London, England

1999 by the Regents of the University of California

Library of Congress Cataloging-in-Publication Data

Shaw, Randy, 1956-

Reclaiming America : Nike, clean air, and the new national activism / Randy Shaw.

p. $\mathrm{cm}$.

Includes bibliographical references and index.

ISBN o-520-21359-9 (alk. paper).--

ISBN 0-520-21779-9 (pbk. : alk paper)

1. Social action-United States. 2. Community organization-United States. 3. Political participationUnited States. I. Title.

$\mathrm{HN}_{6} . \mathrm{S}_{4} 8_{4} 1999$

361.2- de21

98-28700

CIP

Manufactured in the United States of America

$\begin{array}{llllllllll}10 & 9 & 8 & 7 & 6 & 5 & 4 & 3 & 2 & 1\end{array}$

The paper used in this publication is both acid-free and totally chlorine-free (TCF). It meets the minimum requirements of American Standard for Information Sciences-Permanence of Paper for Printed Library Materials, ANSI Z39.48-1984. 
For Anita and Ariel 
